\title{
Life Skills Education Programs; The Bridge to the Employment of the Poors
}

\author{
Didi Mulyadi1 ${ }^{1 a^{*}}$, Unifah Rosyidi1,b, Suryadi 1 ,c \\ ${ }^{1}$ Department of Educational Management, Post Graduate Programs, Jakarta State University,Jakarta, 13120, Indonesia \\ a didi.mulyadi@pertiwi.ac.id; b unifahrosyidi@unj.ac.id; c suryadi@unj.ac.id \\ *Corresponding Author \\ WhatsApp Numbers: [085210843191]
}

How to Cite : Mulyadi, D., Rosyidi, U., Suryadi, S. (2019). Life Skills Education Programs; The Bridge to the Employment of the Poors. International Journal for Educational and Vocational Studies, 1 (5), 434-439

\section{ARTICLE HISTORY}

Received: 13 June 2019

Revised: 22 July 2019

Accepted: 24 August 2019

\section{KEYWORDS}

Life Skilss Education Program;

Non Formal Institutions;

CIPP Evaluation Model;

Unemployment;

Poverty;

\begin{abstract}
Employment is such kind of a very rare opportunity for the poors unable to attend formal schoolings. This research is examining the implementation effectiveness of skills based education program designed by the government through grant and scholarship to reduce the poverty and unemployment. It also tries to compare the design and its result to find whether the program was effectivey implemented or not. This research uses qualitative method through CIPP evaluation model. The research found that in a policy layer, context and input evaluation steps, the life skills education program is comprehensively thought and considered as it covers aspects including the regulation, the program guidance, the fund aids, the curriculla, the guide for selected institutions, the report mechanism. While at the process and product evalauation steps, the reserach found that there were huge gaps in implementation especially at the placement at the industries. There were only less than $10 \%$ of participants entering to work fields while most of its program participants work only as a parttimers which don't provide reguler income,.So the target of decreasing the poverty and reducing the unemployment was not well measured.
\end{abstract}

This is an open access article under the CC-BY-SA license.

\section{INTRODUCTION}

The developing country like Indonesia is facing common problems, poverty and unemployment. The high rate of poverty and unemployment is mostly caused by the low education level especially for those in lower class society. The result is the group can not move their lives quality into better one. The Statistics data show that for the last three years $(2014-2016)$ the rate of the poverty stands at $10,96 \%$, $11,13 \%$ and $10,70 \%$ respectively far above the other Asean countries such as Malayasia which stands at $0,6 \%$, Thailand 10,5\% (ADB, 2016). While the unemployment stands at 5,95\%, 6,18\% and 5,61\% respectively.(Kursus, 2016). This problem if we can say that, can create multiple effects as it can be used as a political campaign. But it is not the case as education is a right for every citizen. It is also constituted in 1945 Indonesia's constitution which states that education is the right of every citizen and the government is responsible for it. The government is aware that without education, the life of the uneducated ones are very difficult.(Mulyadi, 2017). In fact there are a lot of people especially those from the lower class people are unable to attend the formal education.
The answer to the problem is by providing education assessable by all citizens especially by those who were not able to enter formal education in their youth. So the informal education, which doesn't stick with the rules, especially age, is the best answer.(Mayombe, 2017)(Aloud \& Recount, 2017). The Indonesian government is creating skills based education program to reduce the poverty and unemployment rate in Indonesia(Kursus, 2016). The program is intended for those who are from lower class people society. The program is also funded by the government through the scholarship provided to non formal education institutions spreading all over Indonesia. (Sekretaris Negara Republik Indonesia, 2003) (Wartanto, 2019) Non formal education is mandated by the Indonesian constitution No. 20, 2003 on the National Education systems which include non formal education as a part of the whole national education systems. (Sekretaris Negara Republik Indonesia, 2003). On the article 26 it is stated clearly that 1) non formal education is intended to serve the society as a replacement, subtitution and complement to the formal education in the support of life long education; 2) 
non formal education is intended to develop students in mastering knowledge, skills, attitude and profesionalism; and 3) non formal education consists of skill based programs, women empowerment, and early childhood education.

The encripted point is that non formal education is really relevant for those who are not able to enter formal education for some reasons, mostly economy, to gain economics advantage by acquiring skills needed to compete in a formal employment with those having opportunities to enter formal education. Non formal education is also flexible as there is no age limitation compared to those in formal education. Non formal education is also much cheaper and applicable (Burlacu, 2017) (Tudor, 2013). The questions of this paper is whether the life skills education program indeed provide employment opportunity for those from the poors.

This paper is intended to find the answer how the life skills can help government in reducing the poverty and unemployment in Indonesia.

\section{METHODS}

This research uses a combination of qualitative approach with evaluative method in which the data collections were carried out through interviews, field notes, observations, and documentations (Miles, Mathew B, Hubermen, Michael, Saldana, 2014), (Creswell, 2012), (Mislevy, Haertel, \& International, 2005) and decriprive quantitative approach to analyse the quantitative data gained from the result of interview, filed notes, documentation and observation The model uses CIPP model developed by Stufflebeam (Madaus, George F, 2002), (Madaus, George F, 2002).

This research is focused on the analysis between the policy and the products of the programs namely skills based non formal education program initiated by the Directorate of Course and Training Development. This approaches shall provide complete and accurate information and findings as it covers all the steps in implementing the programs. The step started by the initial ideas on how the program is intended and created, the regulations and the guidance of the program. Followed by the availibalities of the fund, curricullum, the non formal institution, the process on how the program is run by the private and independent non formal institutions and finally the result of the program. (Kursus, 2016). By analysing such a comprehensive analysis the researcher believes that the outcome of this research can provide improvement, solution and development or even discontinuation of the program it self.

The first data were taken from 11 non formal education institutions (NFIs) in East Jakarta, Indonesia having imlemented the skills based non-formal education. During the data collection, the researcher interviewed the head of the 11 non formal institutions. The second data were taken from the competency sertification institution, an independent certification agency functioned at measuring the competencies from the participating students of skills based education program. The third data were gained from the industries in which the students work after finishing the program.

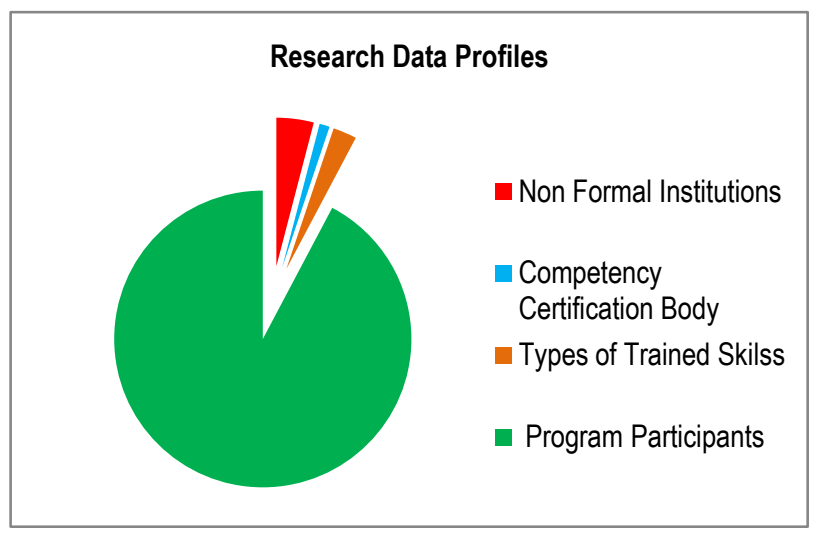

Figure 1. Research Data Profiles

This data is intended at findings the quality of the students and relate it with the curriculum created by the government whether the curriculum meets with the needs of the industries in selected skills. The last data were taken from the government official supervising and creating the program. It is the Directorate of Course and Training Development the Ministry of Education the Republic of Indonesia. The questions are related with the model developed in analysing the program which include context, inputs, process and product (Stufflebeam, 2007). This research focuses on the product evaluation as the end target of the program.

\section{RESULTS AND DISCUSSION}

The research shows that among 11 researched NFIs, the program gains different outputs depending of the program itself. Below is the list of of the institutions, number of students accessing the program, and the types of the skills trained.

\subsection{Context Evaluation}

The result shows that the program has a strong foundation and legal basis as the it lies on the current regulation issued by the government. As we know all that all program designed and conducted by the government shall be with legal basis. The life skills education program was initiated based on the regulation No. 20, 2003 on the National Education System, Government Regulation No. 64, 2012 on the financial aids for early education and non formal education. The backgorund of the program itself focuses on the eradication of the poverty and reducing the unemployment. The program comes to points as the numbers of poverty stands at 5,13\% (Biro Pusat Statistik, 2019) and the poverty line stands at 5,93\% (Biro Pusat Statistik, 2017). The background of the program has been relevant to problems faced by Indonesia. The data of 
poverty and uneployment keep decreasing currently but compared to the population of Indonesia the numbers are still huge. The program has also taken the participation of the society through non formal institutions as the implementers of the program so that the coverage of the program can cover all over Indonesia. It means that the more people especially those without skills and education can gain skills through the program.

\subsection{Input Evaluation}

The government as the policy maker of the program has provided the needed instruments to make the program run smoothly. It includes the availability of the fund in the term of scholarship through the chosen nin formal institution. The non formal institution trying to access the scholarship of this program should compete with others nation wide. The government also provide aids for those institution which do not have necesary infrastructure in making the program successful. The government provide the fund for the implementation of the program itself and the conduct of competency test carried out by the competency test agency. (Kemendikbud, 2008), (Menteri et al., 2008)

The financing education has also important (Michael, Steve O, Kretovics, 2005) (Morales, n.d.) as the targets of the program are those from financially poor family.

The directorate has also provided the curriculla for different skills. The curriculla have been the results of the forum groud discussion among stake holders. Among them is industries where the graduate shall be absorbed. The curriculla themselves relate with the Indonesian Qualification Framework (IQF) (Sekneg RI, 2012). From the training infrastructures the government only chose the institution with well equipped ones. That means the institution with sufficient infrastructures shall have opportunity to access the grant. The last one is the requirement of teachers in making the program successfull. Teachers become pioneers in the management of students because they have an agent role in the progress of students' development (Aliyyah, Widyasari, Mulyadi, Ikhwan, \& Prananosa, 2019). The research found that all teachers and instructors involving in the learning process have the needed requirements. Most of them have the status of teachers assessors at the competency test agency so the mastery of the trained skills are undoubtfull.

\subsection{Process Evaluation}

This evaluation process of the program included the use of the fund disbursed to non formal institutions, program participants recruitment process, and learning process.

The research found that some non formal institution managers and owners said the fund provided by the government is basically sufficient for minimum services but for the better services, they agree that the fund provided shall be given an increase. The amount of the money shall be managed carefully as they have two different needs, providing quality education to guarante the quality of the participants so that they can easily be absorbed by the industries. And the seond managing the money as determinde by the government. The percentage of the spending are as follows, management for $20 \%$, program implementation allocation ; 50\%, learning evaluation ; $15 \%$ and the rest for the industrial placement for $15 \%$. The program recruitment process, from the 11 NFIs, it was found that all the institutions used traditional model when recruiting participants. Most of them used formal channel such as sub district offices to get the participants data. While the learning process it was found that most of the institution spent most of the time (70\%) from 200 hours program for practice while the other $30 \%$ was alocated for theory based teaching. But overall of the evaluation results show that all non formal instituions can manage the money well.

\subsection{Product Evaluation}

Placement in the industries, should be the main objective of this skills based education program. This is in line with the ultimate goal of making this program is to reduce unemployment and poverty. But in practice, the placement in industries is just a mere administrative requirement. The results of research conducted through observation, validation of documents and interviews found that the Non Formal Institutions (NFIs) implementing the program are difficult to find a balanced partner in the placement of graduates of the skills based education program. Even if they have the Memorandum Of Understanding (MOU), that was done between them only.

From the interview result almost all Non formal Institutions (NFIs) can not show data placement of participant in the industries. There are only 2 NFIs (18\%) having the ability to put the program participants industries. While 9 NFIs (82\%) can not show the document that explains their ability to place their graduates in the industries. 9 NFIs (82\%) stated in the interview that in general graduates work in as a freelancers.

This is because the 9 NFIs dealing with the bride's cosmetology and skin beauty skills in which the industry needs more free lancer than permanent ones. While 1 NFI handling baby sitter training, although not formally has an MOU with industry, but the graduates are marketable. This is due to the majority of the graduate service users are households. Even for baby sitter skill the prospective graduate user must queue 2 - 3 months to get the graduate. The prospective user will also be assessed by the Non Formal Institution and required to come to the NFI to make pick-up and conduct direct interviews with prospective workers desired.

Graduate users can not ask the NFI to send their graduates. From the results of interviews with NFI leaders it was found that the obligation of pick-up and even interview in NFI as a way to see the competence of the workforce and as the responsibility of NFIs to the graduates of the skills based education program. With such a model it is also expected that the service user will appreciate the workforce that will be hired. 
From the above research data it is found that informally they have cooperation among them and make MOU among them as a condition of receipt of proposal and escaped to get aid fund, but from actual interview result they do not have a clear MOU with the industry which stated that the intended industries undertakes to be part of the absorption of graduates of the skills based education program.

In fact, when interviews are conducted only about $20 \%$ of graduates of employment skills education programs are able to be absorbed in the industry. And the industry is not a formal industry like the company. For a baby sitter skill graduates as an example, the absorption of $100 \%$ of graduates works on a home employer. For graduates of bridal makeup skills, most of them work on a part-time basis when there is a call to make up the bride. And for sewing skills, only a small percentage work in organizations that provide a monthly salary. Overall the average absorption of graduates of the skills based education programs ranges from $20 \%$. But from a simple point of view, even though they do not formally work in formal institutions, with the skills they possess they can also be entrepreneurs or at least they do not have to charge money if their children need makeup or just sew their clothes and pants for personal use.

Evaluation of product components or results is a very important evaluation because a program can be said to succeed or not is if the product can be in accordance with the planned. According to Kamus Besar Bahasa Indonesis (KBBI) products are goods or services made and added point or value in the production process and become the end result of the production process. . If the skills based education program is considered a production process then all the preparation of the stages of context, inputs, processes and products is a series of production activities that produce products called graduates. So graduates are a result of the teaching and learning process conducted by the NFIs and are supported by the policies issued by the Directorate of Course and Training Development.

Evaluation results show that the evaluation of teaching and learning conducted by the Non Formal Institutions (NFIs) did not conduct written and structured evaluation because the learning process is also not as we imagine. (Nkwake, 2015), (Royes, 2010) They learn 4 times a week but with the flexibility applied by the NFIs, sometimes the training can be individually served. Program participants can add their hours of study as long as they have time and will be served by the NFIs because most of its instructors are the owners of the NFIs and most of them are also home to the NFIs owners.

So flexibility can indeed be applied. Judging from the evaluation results in the form of local skill certificate issued, the researcher concludes that the entire program participants are able to complete the final evaluation which is shown by the release of skill certificate issued by each Non Formal Institutions (NFIs). All Non Formal Institutions (NFIs) establish graduation indicators with the issuance of the certificate. The evaluation stage is an internal evaluation conducted by its Non Formal Institutions (NFIs). Problems and test instruments prepared by NFI executors and supervisors were carried out by instructors who daily meet with participants.

Another aspect in the product component is an evaluation that involves an external party or external quality assurance system where its executing, testers and supervisors are Competency Test Sites (CTS) designated by the Competency Certification Institute (CCI). This competency test has actually been regulated by the National Education Ministerial Regulation No. 70 year 2008 on competency test which states that competence test for learners of NFIs from non formal education unit or self-learning community member and implementation of competency test and competency certificate are conducted by accredited education unit or certification body.

In this case the Directorate is not absolutely mandatory to require the Course and Training Institute to conduct competency tests through the Comprehensive Certification Institution but it is also possible that the NFIs conduct a test of competency in a professional organization or Professional Certification Agency if the skills taught do not have a Competency Certification Body.

Until now the Directorate for Course and Training Development has 33 Competency Certification Institutions for various skills. From the object of research all skills in this skills based education program already have a Competency Certification Institution, namely Competency Certification Body Baby Sitter, Bronze Competency Certification Competency Institution, and Certification Institute of Competition of Clothing. The result of graduate product evaluation in the form of passing competency certification issued by the Competency Certification Institution (CCI) has fulfilled where $100 \%$ of the participants of the work proficiency education program follow competency test at the Competency Certification Institute (CCI) which is in accordance with the skill field.

Aspects of placement in the world of industry world which became the ultimate goal of the success of this work skills education program is the weakest aspect. The results of the evaluation showed that both field observation, interviews with the NFIs and program participants showed that most of the $80 \%$ of their graduates did not work in the industries. Even if they are absorbed and become a workforce, their status is generally as part-time or project-based work, meaning they do not get a monthly salary but are paid on the job-based basis.

If the ultimate goal as stated in the design of this program, it is clear that the purpose of this skills based education program is not successful especially for the skills that become the object of this research. If the goal is to reduce poverty, for example, it is likely to decrease directly but it is difficult to measure because there is no coaching program after the completion of this program. If the ultimate goal is to reduce unemployment then this program has very little impact to reduce unemployment data because most participants of this program are housewives. 
In the broader context, it can be concluded that this work skills education program in the scope of graduation of program participants in the business world and the industrial world becomes irrelevant. This study finds that there is indeed a transfer of knowledge in the lower society with the skills offered.but the final target of becoming an employees at the industries is not realistic. Skills that are researache msut be skills are better off having the ultimate target of entrepreneurship.

\section{CONCLUSION}

Comparing policy and result of the program shall thoroughly be analysed comprehensively as the gap between the result and the policy can become a basis of making better policy or better implementation. It might be great in the policy but really bad in implementation or vice versa. The result expected from the program itself is clearly stated that the end of the program in general is reducing the unemployement and the poverty? The questions is has it been achieved as we see the result of the research?.

In a policy layer, the skills based education program can actually be the correct answer for minimizing gaps between the rich and the poor as they can have regular income by working in the industries with the skills they gained during the training. The program itself is designed in developing skills needed by industries. The government has actually prepared comprehensively starting from the context processes which consist of regulation and program guidance, input processes which consists of curriculum, funding and assingment of Non Formal Institutions (NFIs), implementation processes, and also product processes.

But in the implementation is as most of the participants are housewives and at around $35-40$ years old, so it is very difficult for them to enter the formal jobs with monthly income. The participants are mostly able to wark as part timers with project based income which can not be measured well. And finally the result expected from this program is not achieved well as it can be seen from the absorption of the program participants into industries.

The solution is the government needs to redesign the program. If the program is intended to provide the participants the skills to enter the umployment field so the requirement for the participants should be fresh graduate or maximum at the age of 22 . While if the program is intended to provide life skills for participants so they need to be given an entrepreneurship skills so that they can use their skills to develop their own business and get the income. If both are carried out seriously, the target of reducing unemployment and poverty can work well and influence significantly.

\section{REFERENCES}

Aliyyah, R. R., Widyasari, Mulyadi, D., Ikhwan, S., \& Prananosa, A. G. (2019). Manajemen Kesiswaan Pada
Sekolah Dasar. Didaktika Tauhidi: Jurnal Pendidikan Guru Sekolah Dasar, 6(April). https://doi.org/10.30997/dt.v6i1.1355

Aloud, R., \& Recount, T. (2017). Journal of Educational Research and Evaluation. Jurnal of Educational and Evaluation, 6(1), 10-18.

Biro Pusat Statistik. (2017). Kemiskinan sd 2017 Indonesia. Jakarta: Biro Pusat Statistik.

Biro Pusat Statistik. (2019). Tingkat Pengangguran Terbuka Tahun 2015 - 2018. Jakarta: Biro Pusat Statistik.

Burlacu, A. (2017). The Importance of Non-Formal Education and the Role of NGOs in its Promotion. In Europian INtegration: Realities and Perspectives (Vol. 1, pp. 863-867). The 7th Edition of The International Workshop.

Creswell, J. W. (2012). Educational Reserach. Book. Boston.

Kemendikbud. PP No. 48 Tahun 2008 Tentang Pnedanaan Pendidikan (2008).

Kursus, D. P. (2016). Petunjuk Teknis Program Pendidikan Kecakapan Kerja. Direktorat Pembinaan Kursus.

Madaus, George F, D. L. S. (2002). Evaluation Models; Viewpoints on Educational and Human Services Evaluation (2nd ed.). Kluwer Academic Publishers.

Mayombe, C. (2017). Integrated non-formal education and training programs and centre linkages for adult employment in South Africa. Australian Journal of Adult Learning, 57(1), 106-125.

Menteri, P., Nasional, P., Uji, T., Bagi, K., Didik, P., Dan, K., Masyarakat, W. (2008). 4 . Keputusan Presiden Nomor 187 / M Tahun 2004 mengenai Pembentukan Kabinet Indonesia Bersatu , sebagaimana telah diubah terakhir dengan Keputusan Presiden Nomor 77 / P Tahun.

Michael, Steve O, Kretovics, M. A. (2005). Financing Hihger Education in a Global Market (Vol. 2). New Yok: Algora Publishing.

https://doi.org/10.1016/j.patrec.2005.01.006

Miles, Mathew B, Hubermen, Michael, Saldana, J. (2014). Qualitative Data Analysis. Book (2nd ed.). Sage Publishing.

Mislevy, R. J., Haertel, G. D., \& International, S. R. I. (2005). Implications of Evidence-Centered Design for Educational Testing.

Morales, F. X. S. (n.d.). Aspects of financing non-formal education, $\operatorname{XIII}(\mathrm{x})$.

Mulyadi, D. (2017). Pengembangana Kepedulian Masyarakat TPA Bantar Gebang akan Pentingnya Pendidikan dalam Meningkatkan Taraf Hidup Mereka. In Senaspro. Malang: UMM Malang Press.

Sekneg RI. (2012). Peraturan Presiden No. 8 Tahun 2012 tentang KKNI.

Sekretaris Negara Republik Indonesia. (2003). UU No 20 Tentang Sistem Pendidikan Nasional. Jakarta. 
Stufflebeam, D. L. (2007). CIPP evaluation model checklist. Evaluation checklists project.

https://doi.org/10.1007/978-94-007-6869-7

Tudor, S. L. (2013). Formal - Non-formal - Informal in Education. Procedia - Social and Behavioral Sciences, $76,821-826$.

https://doi.org/10.1016/j.sbspro.2013.04.213

Wartanto. (2019). Display Kursus. Jakarta: Kemendikbud. 